\title{
Burnout Syndrome in Mental Health Professionals: psychiatric hospital setting
}

\author{
Irena Velimirović ${ }^{1}$, Mirta Vranko ${ }^{1}$, Martina Ferić ${ }^{1}$, Tihana Jendričko $^{1}$ \\ ${ }^{1}$ University Psychiatric Hospital Vrapče, Zagreb, Croatia
}

\begin{abstract}
Burnout is frequently mentioned as a problem in the mental health field. As a type of prolonged response to chronic job-related stressors, has a special significance in health care where staff experience both psychological-emotional and physical stress. The aim of the paper was to determine the level of stress in professionals working in psychiatric hospital, as well as to explore possible differences in stress level regarding the different characteristic of participants as sex, level of education, marital status, working hours etc. The Burnout Clinical Subtypes Questionnaire was used. Study was conducted from July to December 2014, and from April to May 2015. The sample of 141 participants who work in mental health profession consists of $39.9 \%$ male and $68.1 \%$ female, average age of 38.98 years. Overall results show that participants have lower scores on all subscales. The results showed that there is moderate burnout experience in the sense that participants feel overload when they try to maximize their reward by taking on a volume and pace of work that become excessive. This questionnaire can be a very useful instrument for future evaluation and designing interventions and different treatment strategies for subtypes of burnout.
\end{abstract}

Keywords: burnout, mental health professionals, psychiatric hospital

Copyright (C) 2017 KBCSM, Zagreb

e-mail: alcoholism.kbcsm@gmail.com•www.http//hrcak.srce.hr/acoholism

\section{Introduction}

Burnout was first described in the early 1970s, and until now it has been presented as a complex phenomenon, focused on job-related stress that encompasses three dimensions: emotional exhaustion, depersonalization or cynicism and reduced personal accomplishment (presents negative self - evaluation of

Correspondence to: Tihana Jendričko

University Psychiatric Hospital Vrapče, Bolnička cesta 32, Zagreb, Croatia

e mail: tjendricko@gmail.com one's work with consumers or overall job effectiveness [1].

Burnout is frequently mentioned as a problem in the mental health field [2]. Despite its prevalence and association with a number of negative outcomes, little attention has been directed toward reducing or preventing burnout among mental health professionals. Many researchers consider burnout to be a job-related stress condition [3], in fact, burnout closely resembles the ICD-10 diagnosis of job-related neurasthenia [1]. Even though burnout is correlated with other mental health conditions/prob- 
lems, such as anxiety and depression [1], some researchers also support that burnout is a construct distinct from these other mental health disorders and from a general stress reaction [3].

Burnout, as a type of prolonged response to chronic job-related stressors, has a special significance in health care where staff experience both psychological-emotional and physical stress. As a risk factor specific to human service occupations, burnout is of interest to researchers and practitioners in the mental health field. There is a growing interest for research of the effects of psychosocial work environment on health care staff since they are at high risk for burnout, role conflict and job dissatisfaction. Burnout and the other negative aspects of the job of health care staff have major behavioral and health implications [4].

Burnout among nurses in particular has been reported to be higher than other health professionals owing it to the nature of their work [5]. Authors Sahrain et al. [6] found that nurses of psychiatry wards showed significantly higher levels of emotional exhaustion and depersonalization in comparison with nurses working in other departments. Psychiatrists are also a group that is one of the most vulnerable groups of medical specializations for burnout. There are many external and internal factors that make psychiatry such a stressful profession. Those factors include patient violence and suicide, limited resources, crowded inpatient wards, changing culture and mental health services, high work demands, poorly defined roles of consultants, responsibility without authority, inability to effect systemic change, conflict between responsibility toward employers vs. toward the patient, and isolation.
Also, it is important to stress out that psychiatrists use themselves as tools in their work, and as such are more exposed to job related stressors like the gap between the knowledge they gained and the rapidly changing trends in the profession and the administrative and legal demands [7]. Deahl \& Turner [8] tried to identify factors that make psychiatry such a vulnerable profession for burnout and have detected a few factors: violence and the fear of violence, limited resources, crowded inpatient wards and an increasing culture of blame creeping into the mental health services. Similar results were obtained among nurses indicating that stress related to staff issues (including poor staff management, resource inadequacy and security risks) is the most important in determining burnout and job satisfaction [9]. Kumar, Hatcher \& Huggard [10] conducted a selective literature review to expand on two systematic reviews to examine etiology, prevalence, and consequences of burnout in psychiatrists. They suggested to identify possible protective factors, and to utilize those information in creating interventions that protect or mitigate the effect of work - place stress on psychiatrists. Jenkins \& Elliott [11] did a research among nurses in acute mental health settings and reported that the lack of adequate staffing was the main stressor reported by qualified staff, while dealing with physically threatening, difficult or demanding patients was the most stressful aspect for unqualified staff. Furthermore, qualified nurses reported significantly higher workload stress than unqualified staff. Rathod et al. [12] did a large survey on work related stress among psychiatrists working in the Wessex Region in which the psychiatrists self-reported hours or long hours of duty, dealing with difficult and hostile relatives of patients, arranging admissions, paper work, 
balancing personal and professional lives and managing suicidal or homicidal patients as particularly stressful experiences in their jobs. Kumar, Hatcher \& Huggard [10] reviewed factors that may predispose, precipitate and perpetuate the burnout syndrome among psychiatrists. Some of the personal traits they possess may cause them to internalize their stressful experience more than other physicians, and they report that they often feel self-doubt, fear and fatigue.

Most of the research regarding burnout has focused on the role of work characteristics has burnout as a work-related state of mind, however, the question why some employees develop the burnout syndrome while others working in the same environment don't, leaves some questions unanswered [13]. Langelaan, Bakker, Dooren \& Schaufeli [14] wanted to explore the relationship between work engagement and burnout so they conducted a research among 572 employees to examine whether burnout had a positive antipode that is work engagement. The research has shown that burnout and engagement are each other's opposites, but we also need to take into consideration the personality and temperament of the employees. Work engagement is connected to extraversion and mobility, the capacity to adapt to changing environments, which is not one of the characteristics of people vulnerable to burn out. Piko [15] investigated the relationship between the burnout, role conflict and job satisfaction in the sample of Hungarian health care staff. The study has shown that emotional exhaustion is strongly related to job dissatisfaction that is also shown to be a negative predictor of each type of burnout subscale. Also, level of education was inversely related to job satisfaction. Leiter \& Harvie [16] did a review of studies relating to burnout among mental health workers and included psychiatrists, psychologists, counselors, mental health social workers nurses and occupational therapists which work not only in hospitals but in other institutions providing mental health services. Most of the studies did not find significant connections between gender and level of burnout [17], although some of the studies have shown that small psychotherapists have higher scores on personal accomplishment scales and lower on emotional exhaustion [18] Vorkapić \& Mustapić [19] points out that factors such as work conditions, emotions about work, work organization and certain personality traits show a significant relationship with all three burnout dimension (frenetic, underchallenged and worn-out) among substance abuse counsellors. Demir, Ulsoy M. \& Ulsoy M.F. [20] did a study aiming to determine the factors causing burnout in professional and private lives of 333 nurses working in the university and state hospitals. The results have shown that nurses with higher education, more work experience and a higher status have lower scores on the burnout scale, however working night shifts increases those scores. In addition, nurses who have problems in relations with the other team members and are not satisfied with their work conditions have higher levels of burnout. Lin, John \& Mc Weigh [21] found that age, years of experience and professional title had a significant positive relationship with emotional exhaustion, meaning, that older and married nurses with more personal responsibilities and in a more senior position experienced higher levels of emotional exhaustion. Different results are shown in the study of Chou, $\mathrm{Li} \& \mathrm{Hu}$ [22], as their findings point out that being young, working overtime and being a nurse or physician assistant, engaged in a job with high strain, frequent over- 
commitment and low social support is associated with high burnout.

Schimp [23] found that age was the strongest predictor of burnout, followed by educational level; persons who are older and more educated are less likely to experience burnout. Aguwa, Nduka \& Arinze-Onyia [24] did a research regarding demographic variables and found that female health workers and workers with lower education are at more risk of burnout than male health workers and workers with higher education. However, age, marital status and years of work did not significantly affect burnout score. Different results were obtained by Matin, Kalai \& Anvari [25] in their research about the effect of variables such as age, gender, marital status and educational level on burn out and its consequences. The results of the study show that the demographic variables don't affect the relationship of job burnout and its consequences. Maslach, Schaufeli \& Leiter [26] did a systematic review on the factors affecting the burnout; part of their research was focused on demographic characteristics. Age is the one of the characteristics that is most consistently related to burnout, level of burnout is reported to be higher among younger employees. As age is usually related to work experience, burnout is a higher risk in the earlier period of one's career. Variable of sex has not been found as a strong predictor of burnout, regarding to marital status those who are unmarried (especially men) are more prone to burnout compared with those who are married. Singles experience even higher burnout levels than those who are divorced. Similar results, regarding age, are shown in a meta-analysis in which the age and work setting variables are the most significant indicators of emotional exhaustion and depersonalization. Age and work hours variables had the most significant positive correlations with burnout [27]. Leiter \& Harvie [16] did a review about burnout among mental health workers and found that most of the studies don't find a significant relationship between burnout and gender, burnout and marital status and burnout and level of education, regarding the relationship between years of experience and burn out they found negative relationships with emotional exhaustion and depersonalization and a positive relationship with personal accomplishment. Vredenburgh et al. [28] found an inverse relationship between age and burnout among counseling psychologists.

Despite the fact that there were a great number of researches in the past decade, many research results are not unambiguous and there is a need for research that is oriented to a specific population, such as health care personnel in psychiatry, in order to respond to their individual needs and prevent the appearance of burnouts.

Goals of this paper are to determine the level of stress of professionals working in psychiatric institutions and to explore the possible differences in stress level regarding some individual characteristic of participants such as gender, age, level of education, personal relationship status as well as working conditions like overtime work and the length of services.

\section{Subjects and Methods}

\section{Subjects}

The sample in this research consists of 141 participants who worked in University Psychiatric Hospital Vrapče, Zagreb, Croatia at the time of the research. Regarding the gender, $31.9 \%$ of participants were male and 
68.1\% female. Average age was 38.98 years. Most of the participants have a high school degree level (62.9\%), 14.3\% of them have a bachelor's degree, $20.0 \%$ have a degree at masters level and 2.9\% participants have a Ph.D. diploma. The sample consists of 7.1\% medical doctors (psychiatrists), 53.9\% nurses, $24.8 \%$ medical technicians, $3.5 \%$ occupational therapists and $10.6 \%$ of other professional staff (psychologists, social pedagogue and social workers). Regarding the personnel's relationship status, $15.6 \%$ of participants were in a relationship, $2.8 \%$ were engaged, $61 \%$ were married, $9.9 \%$ were single, $7.8 \%$ were divorced and $2.8 \%$ were widows. By the length of the services at the time of the research, most of the participants worked from 16 to 20 years $22.3 \%, 9.4 \%$ worked from 11 15 years, $17.0 \%$ worked up to 5 years, and $23.0 \%$ worked more than 25 years. Average length of service was 17.5 years. Participants reported that $12.1 \%$ of them worked overtime several times a week, $7.8 \%$ worked overtime once of week, $28.4 \%$ work overtime several times a month, $12.1 \%$ work overtime once a month and $36.2 \%$ reported that they do not work overtime. Most of the participants had a full-time permanent employment contract $(92.2 \%)$.

\section{Methods}

Burnout is usually described as a uniform entity with similar etiology and symptoms, but the clinical experience stresses out the need to define different types of burn out because it manifests in different ways depending on the level of dedication to work [29]. The author [29] proposed a typology of three subtypes, frenetic, under challenged, and worn-out. Individuals who fall into the group of frenetic type are very involved in their job, put a lot of time and effort in their jobs, have a great sense of ambition and need for achievement, but they also tend to be overwhelmed because they often neglect their own needs, such as health and personal life [30]. The "underc hallenged" burnout subtype is influenced by the occupation type. It appears in indifferent and bored individuals who do not find personal development in their work. 'Indifference' is lack of concern, interest and enthusiasm in work-related tasks; 'boredom' is caused by the understanding of work as a mechanical and routine experience with little variation in activities; and 'lack of development' is the absence of personal growth experiences for individuals together with their desire for taking on other jobs where they can better develop their skills [30]. The "worn-out" burnout subtype is determined by the rigidity of the organizational structure of an individual's workplace and is characterized by a lack of control over results, lack of recognition for efforts and neglect of responsibilities. 'Lack of control' is the feeling of helplessness as a result of dealing with many situations that are beyond their control; 'lack of acknowledgement' is the belief that the organizations those individuals work for fail to take their efforts and dedication into account; and 'neglect' refers to individuals' disregard as a response to any difficulty [30]. Burnout Clinical Subtypes Questionnaire' (BCSQ-12) measures the aforementioned subtypes of burnout. Every subscale is made of three dimensions:

- Frenetic subscale - Involvement, Ambition and Overload

- Under challenged subscale - Indifference, Lack of development and Boredom

- Worn-out subscale - Neglect, Lack of acknowledgement and Lack of control 
Participants have a Likert-type scale with seven response options that are scored from 1 ('totally disagree') to 7 ('totally agree'). The factorial validity of the BCSQ-12 presents consistent results in the study population, with $\alpha \geq 0.80$ reliability for each of the constituent dimensions and good power for explaining the burnout standard measures [30].

\section{Data collection and statistics}

Data were collected from July to December, 2014 and from April to May 2015. After the Ethics Committee of the clinic approved the research, the surveys were distributed among all the departments in the clinic. SPSS package (version 18) was used for data processing. In order to answer the research questions we used the following methods: descriptive statistics, T-test for Independent sample and One-way ANOVA.

\section{Results}

The first aim of this paper was to determine the level of stress of professionals working in a psychiatric institution.

Overall results show that participants have lower scores on all subscales, which indicates a low to moderate stress level at work (Figure 1)

Subscale Frenetic mean is 3.31. Participants have a slightly higher result on the dimension of Involvement, followed by Ambition and the lowest score on this scale is on the dimension of Overload. Participants reported moderate level of effort required to overcome difficulties at work, and less then moderate need to obtain success and achievement at work. Regarding the overload, there is a less than moderate level of risking health and neglecting personal life in pursuit of good results. Nevertheless, the participants have the highest score on this subscale taking into consideration the other two.

Under challenged subscale mean is 2.57 . By looking at the results scored on the subscale dimensions it can be seen that the lowest scores are at the dimension Indifference followed by Boredom and Lack of development. These results show that participants reported low level of indifference and boredom at work. Moreover, the result shows that participants reported that they feel like their work position and context offers certain opportunities for development of their skills, talents and other abilities.

Worn out subscale mean is 2.72 . The highest scores are on dimension Lack of acknowledgment, followed by Lack of control and Neglect. The results show that participants reported low level of neglect toward work, meaning there is low level of giving up in time of difficulties. Participants reported moderate level of lack of recognition for efforts (from clients, colleagues, institution) and moderate level of feeling helplessness as a result of dealing with many situations that are beyond their control.

Second aim of the paper was to explore possible differences in stress level regarding the different characteristic of participants as gender, age, level of education, personal relationship status as well as working conditions like overtime work and length of services. The differences were explored by subscales and dimensions scores.

The result of analysis showed that there are no significant differences in any subscales regarding the gender of participants (Frenetic $\mathrm{p}=0.750$, Underchallenged $\mathrm{p}=0.613$, Worn out $\mathrm{p}=0.112$ ).

Analysis results showed that there are no significant differences in any subscales 


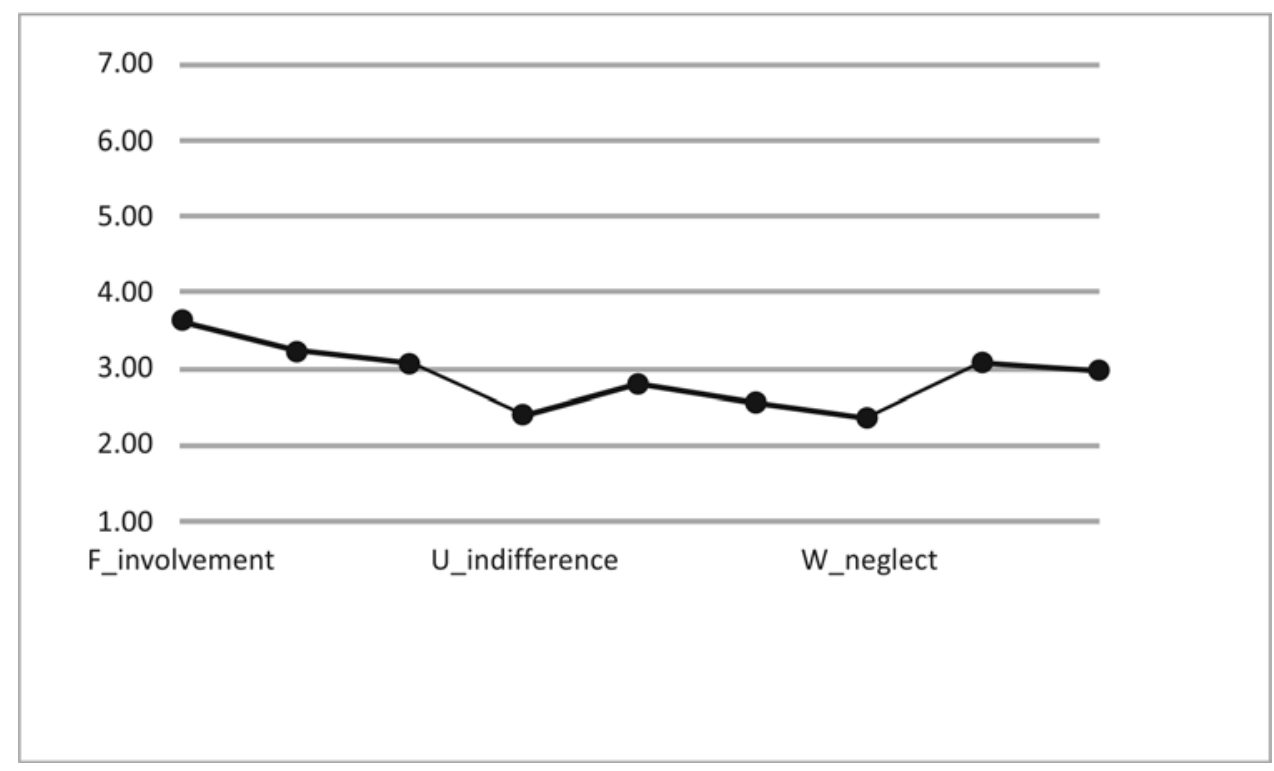

Figure 1. Means by subscales dimensions

regarding the age of participants (Frenetic $\mathrm{p}=0.671$, Underchallenged, $\mathrm{p}=0.456$, Worn out $\mathrm{p}=0.822$ ). Analysis results (One-way Anova) showed that there is a significant difference in the subscales Underchallenged $(p=0.000)$ and Worn out $(p=0.000)$.

By looking at Table 1. it can be seen that participants with higher level of education have lower scores on scale Underchallenged. In the Worn out scale we notice the same trend with the exception of bachelor and master level of education which ,switch places".

In order to further explore the differences One-way Anova was conducted on dimensions of Underchallenged and Worn out.

From the Table 2. it can be seen that there is a significant difference in all three dimensions of Underchallenged and Worn out subscales $(\mathrm{p} \leq 0.05)$. Regarding the Underchallenged subscale dimensions, the same trend

Table 1. Means of Underchallenged and Worn out regarding the participants level of education

\begin{tabular}{cccc}
\hline & Subscales & $\begin{array}{c}\text { Underchallenged } \\
\text { mean }\end{array}$ & $\begin{array}{c}\text { Worn out } \\
\text { mean }\end{array}$ \\
\hline \multirow{3}{*}{ Education level } & high school level & 2.80 & 2.89 \\
& bachelor level & 2.28 & 2.35 \\
& master level & 2.14 & 2.52 \\
& Ph.D level & 1.85 & 2.31 \\
\hline
\end{tabular}


Table 2. Differences regarding the participants' level of education by subscales Underchallenged and Worn out dimensions

\begin{tabular}{|c|c|c|c|c|c|c|}
\hline Subscales_dimensions & & $\begin{array}{l}\text { sum of } \\
\text { squares }\end{array}$ & $\mathrm{df}$ & mean square & $\mathrm{F}$ & Sig \\
\hline \multirow[t]{3}{*}{$\begin{array}{l}\text { Underchallenged _ } \\
\text { indifference }\end{array}$} & $\begin{array}{r}\text { Between } \\
\text { Groups }\end{array}$ & 13.703 & 3 & 4.568 & 7.707 & 0.000 \\
\hline & Within Groups & 77.637 & 131 & 0.593 & & \\
\hline & Total & 91.340 & 134 & & & \\
\hline \multirow[t]{3}{*}{$\begin{array}{l}\text { Underchallenged_lack of } \\
\text { development }\end{array}$} & $\begin{array}{r}\text { Between } \\
\text { Groups }\end{array}$ & 7.972 & 3 & 2.657 & 3.855 & 0.011 \\
\hline & Within Groups & 91.682 & 133 & 0.689 & & \\
\hline & Total & 99.654 & 136 & & & \\
\hline \multirow[t]{3}{*}{ Underchallenged_boredom } & $\begin{array}{r}\text { Between } \\
\text { Groups }\end{array}$ & 16.812 & 3 & 5.604 & 12.463 & 0.000 \\
\hline & Within Groups & 58.903 & 131 & 0.450 & & \\
\hline & Total & 75.715 & 134 & & & \\
\hline \multirow[t]{3}{*}{ Worn out_neglect } & $\begin{array}{r}\text { Between } \\
\text { Groups }\end{array}$ & 5.817 & 3 & 1.939 & 6.311 & 0.000 \\
\hline & Within Groups & 41.482 & 135 & 0.307 & & \\
\hline & Total & 47.299 & 138 & & & \\
\hline \multirow[t]{3}{*}{$\begin{array}{l}\text { Worn out_lack of } \\
\text { acknowledgement }\end{array}$} & $\begin{array}{r}\text { Between } \\
\text { Groups }\end{array}$ & 7.515 & 3 & 2.505 & 4.269 & 0.006 \\
\hline & Within Groups & 79.211 & 135 & 0.587 & & \\
\hline & Total & 86.726 & 138 & & & \\
\hline \multirow[t]{3}{*}{ Worn out_lack of control } & $\begin{array}{r}\text { Between } \\
\text { Groups }\end{array}$ & 10.661 & 3 & 3.554 & 6.788 & 0.000 \\
\hline & Within Groups & 70.669 & 135 & 0.523 & & \\
\hline & Total & 81.330 & 138 & & & \\
\hline
\end{tabular}

appears - higher level of education, lower indifference and boredom at work and lower assessment of dimension lack of development. In Worn out subscale dimensions, results aren't so unambiguous but the trend stays almost the same (exception is in the dimension Neglect).

There is a significant difference (One-way Anova) in subscale Frenetic regarding the personal relationship status $(p=0.012)$. By looking at the means (Table 3.) it can be seen that the participants who are single (category widow and single) had the lowest results. Those who are engaged and in a relationship had the highest results.

There is a significant difference in all three dimensions of Frenetic subscales ( $\mathrm{p} \leq 0.05$, One-way Anova). Results showed (Figure 3.) that engaged participants and ones who are in a relationship assessed the highest effort they 


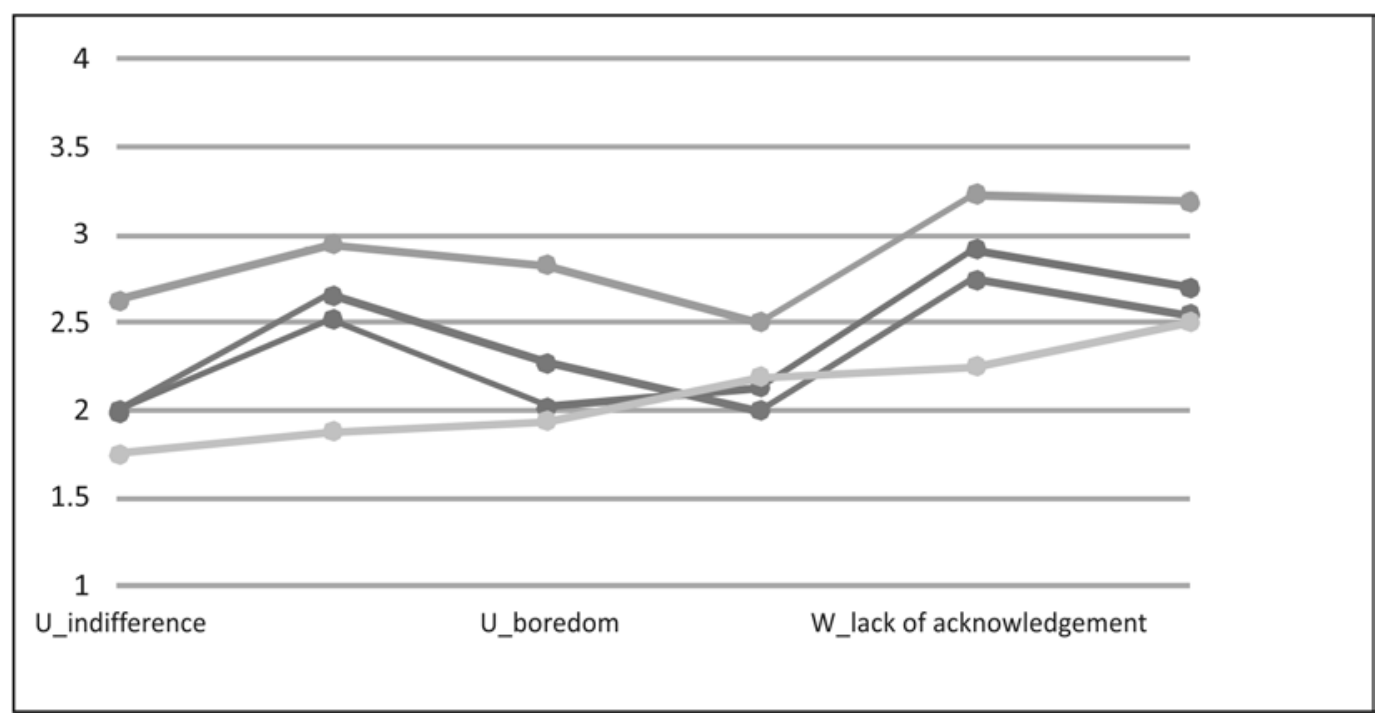

Figure 2. Subscales Underchallenged and Worn out dimensions means regarding the participants' level of education

have to make to overcome difficulties at work. Participants who are single had the lowest results on this dimension. This same trend is present in dimension Ambition. In dimension Overload the highest results were shown by the participants who are engaged, followed by the once who are divorced. Participants who are single and widows had the lowest results.
The results of analysis (One-way Anova) show that there is a significant difference in subscale Frenetic $(p=0.038)$ and Underchallenged $(p=0.002)$. Participants who don't work overtime had the lowest scores on both subscales. The ones who work overtime once a week had the highest results on Frenetic subscale, and those who work overtime once

Table 3. Means of Frenetic scale regarding the participants personal relationship status

\begin{tabular}{llc}
\hline Subscale & & Frenetic mean \\
\hline Relationship status & single & 3.06 \\
& in relationship & 3.54 \\
& engaged & 3.92 \\
& married & 3.28 \\
& divorced & 3.35 \\
& widow & 2.92 \\
\hline
\end{tabular}




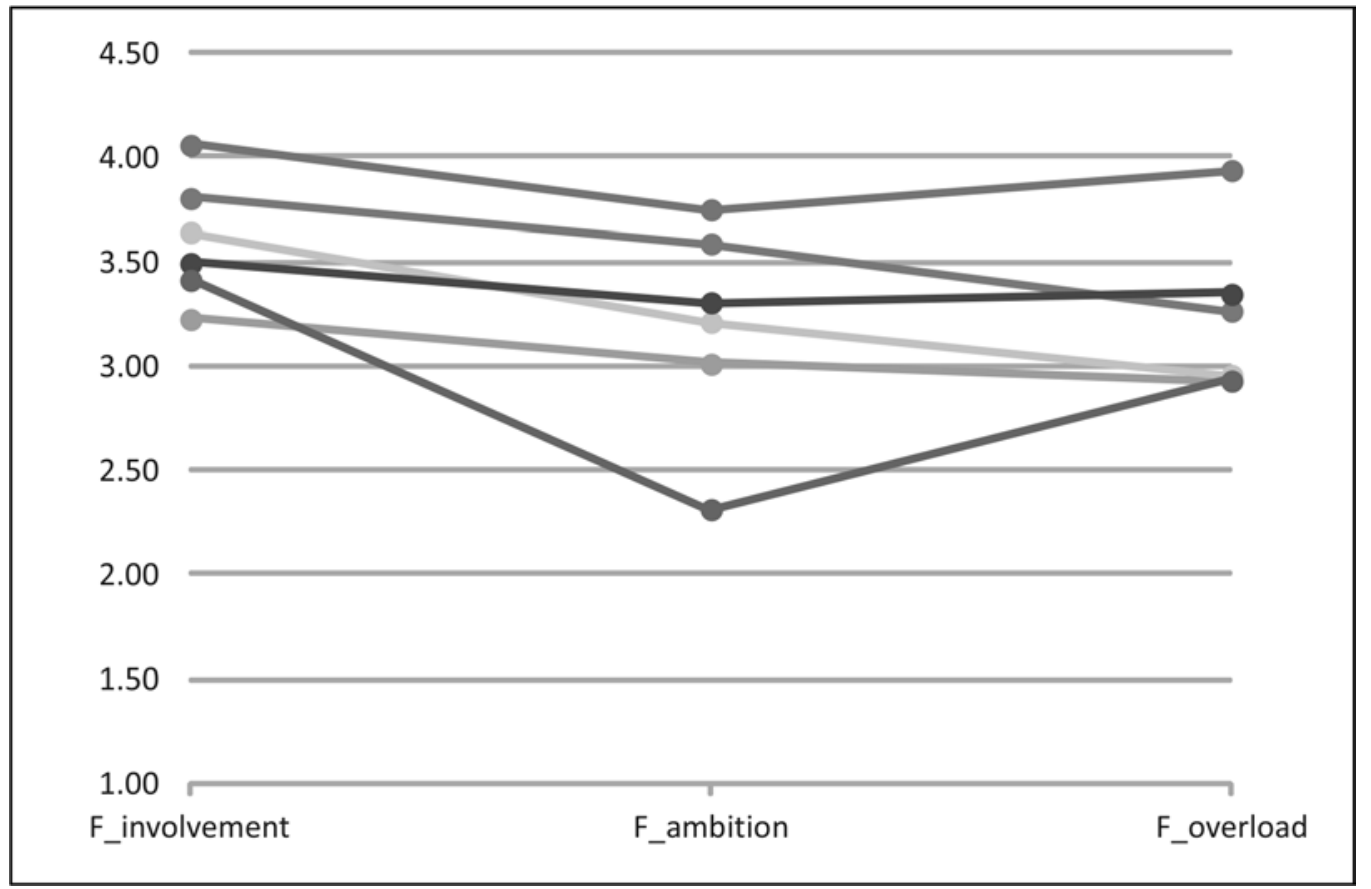

Figure 3. Subscales Frenetic dimensions means regarding the participants' personal relationship status

a month on Underchallenged subscale (Table 5.)

From Table 6. it can be seen that there are significant difference in dimension Overload (subscale Frenetic) and all three dimensions of subscale Underchallenged ( $\mathrm{p} \leq 0.05)$.

The participants who don't work overtime ranked the lowest on all dimensions and

Table 4. Differences regarding the participants' personal relationship status by subscale Frenetic dimensions

\begin{tabular}{lrrrrrr}
\hline \multirow{2}{*}{ Subscales_dimensions } & & sum of & & mean & \\
squares & df & square & F & \multicolumn{1}{c}{ Sig } \\
\hline Frenetic_involvement & Between Groups & 3.977 & 5 & 0.795 & 2.360 & 0.044 \\
& Within Groups & 44.162 & 131 & 0.337 & & \\
& Total & 48.140 & 136 & & & \\
Frenetic_ambition & Between Groups & 7.696 & 5 & 1.539 & 3.531 & 0.005 \\
& Within Groups & 55.797 & 128 & 0.436 & & \\
Frenetic_overload & Total & 63.493 & 133 & & & \\
& Between Groups & 5.983 & 5 & 1.197 & 2.418 & 0.039 \\
& Within Groups & 65.336 & 132 & 0.495 & & \\
\hline
\end{tabular}


Table 5. Means Frenetic and Underchallenged subscale regarding the participants' overtime work

\begin{tabular}{|c|c|c|c|}
\hline Subscales & & Frenetic mean & $\begin{array}{c}\text { Underchallenged } \\
\text { mean }\end{array}$ \\
\hline \multirow[t]{5}{*}{$\begin{array}{l}\text { Frequency of } \\
\text { work }\end{array}$} & overtime several days a week & 3.27 & 2.56 \\
\hline & once a week & 3.58 & 2.70 \\
\hline & several days a month & 3.40 & 2.46 \\
\hline & once a month & 3.50 & 3.18 \\
\hline & no overtime & 3.15 & 2.37 \\
\hline
\end{tabular}

Table 6. Differences regarding the participants overtime work status by Frenetic and Underchallenged subscale dimensions

\begin{tabular}{|c|c|c|c|c|c|c|}
\hline Subscales_dimensions & & $\begin{array}{l}\text { sum of } \\
\text { squares }\end{array}$ & df & $\begin{array}{l}\text { mean } \\
\text { square }\end{array}$ & $\mathrm{F}$ & Sig \\
\hline \multirow[t]{3}{*}{ Frenetic_involvement } & $\begin{array}{r}\text { Between } \\
\text { Groups }\end{array}$ & 1.724 & 4 & 0.431 & \multirow[t]{3}{*}{1.206} & \multirow[t]{3}{*}{0.311} \\
\hline & $\begin{array}{l}\text { Within } \\
\text { Groups }\end{array}$ & 45.728 & 128 & 0.357 & & \\
\hline & Total & 47.452 & 132 & & & \\
\hline \multirow[t]{3}{*}{ Frenetic_ambition } & $\begin{array}{r}\text { Between } \\
\text { Groups }\end{array}$ & 1.678 & 4 & 0.419 & \multirow[t]{3}{*}{0.882} & \multirow[t]{3}{*}{0.477} \\
\hline & $\begin{array}{l}\text { Within } \\
\text { Groups }\end{array}$ & 59.005 & 124 & 0.476 & & \\
\hline & Total & 60.683 & 128 & & & \\
\hline \multirow[t]{3}{*}{ Frenetic_overload } & $\begin{array}{r}\text { Between } \\
\text { Groups }\end{array}$ & 10.150 & 4 & 2.538 & \multirow[t]{3}{*}{5.394} & \multirow[t]{3}{*}{0.000} \\
\hline & $\begin{array}{l}\text { Within } \\
\text { Groups }\end{array}$ & 60.211 & 128 & 0.470 & & \\
\hline & Total & 70.361 & 132 & & & \\
\hline \multirow[t]{3}{*}{$\begin{array}{l}\text { Underchallenged_indiffer- } \\
\text { ence }\end{array}$} & $\begin{array}{r}\text { Between } \\
\text { Groups }\end{array}$ & 10.653 & 4 & 2.663 & \multirow[t]{3}{*}{4.240} & \multirow[t]{3}{*}{0.003} \\
\hline & $\begin{array}{l}\text { Within } \\
\text { Groups }\end{array}$ & 79.144 & 126 & 0.628 & & \\
\hline & Total & 89.797 & 130 & & & \\
\hline \multirow[t]{3}{*}{$\begin{array}{l}\text { Underchallenged_lack of } \\
\text { development }\end{array}$} & $\begin{array}{r}\text { Between } \\
\text { Groups }\end{array}$ & 8.714 & 4 & 2.178 & \multirow[t]{3}{*}{3.161} & \multirow[t]{3}{*}{0.016} \\
\hline & $\begin{array}{l}\text { Within } \\
\text { Groups }\end{array}$ & 88.218 & 128 & 0.689 & & \\
\hline & Total & 96.932 & 132 & & & \\
\hline \multirow[t]{3}{*}{ Underchallenged_boredom } & $\begin{array}{r}\text { Between } \\
\text { Groups }\end{array}$ & 9.504 & 4 & 2.376 & \multirow[t]{3}{*}{4.608} & \multirow[t]{3}{*}{0.002} \\
\hline & $\begin{array}{l}\text { Within } \\
\text { Groups }\end{array}$ & 64.961 & 126 & 0.516 & & \\
\hline & Total & 74.465 & 130 & & & \\
\hline
\end{tabular}




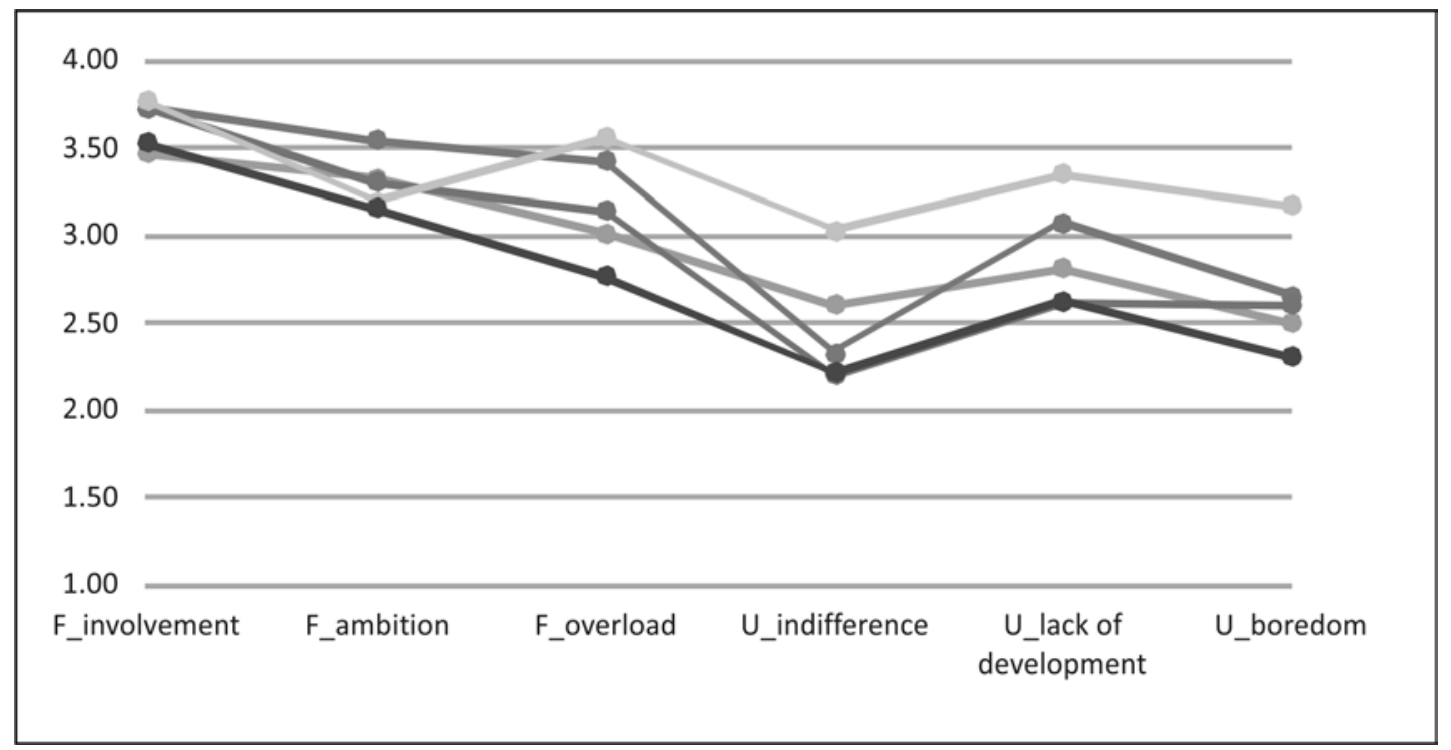

Figure 4. Subscales Frenetic and Underchallenged dimensions means regarding the participants' overtime work

the participants who work overtime once a month and once a week assessed overload dimension with the highest score (Figure 4.). Participants who work overtime once a month assessed all three dimensions of Underchallenged subscale the highest, meaning they feel more indifferent towards the work, they see less opportunities for development and feel more boredom than other groups of participants.
The analysis results (One-way Anova) showed that there is a significant difference in subscale Worn out ( $\mathrm{p}=0.016)$.

From Table 7. it can be seen that the participants who works up to 5 years had the lowest results, followed by those who work 25 years and more.

There is a significant difference $(p \leq 0.05$, One-way Anova, Table 8.) at the dimensions Lack of acknowledgement and Lack of con-

Table 7. Means of Worn out scale regarding the participants' length of service

\begin{tabular}{lcc}
\hline Subscale & Worn out mean \\
\hline & up to 5 & 2.43 \\
Length of services & $6-10$ & 3.00 \\
(years) & $11-15$ & 2.72 \\
& $16-20$ & 2.68 \\
& $21-25$ & 3.02 \\
& $25-30$ & 2.63 \\
& 31 and more & 2.57 \\
\hline
\end{tabular}


Table 8. Differences regarding the participants' length of service status by subscale Worn out dimensions

\begin{tabular}{lrrrrrc}
\hline Subscales_dimensions & & $\begin{array}{c}\text { sum of } \\
\text { squares }\end{array}$ & df & $\begin{array}{c}\text { mean } \\
\text { square }\end{array}$ & F & Sig \\
\hline Worn out_neglect & Between Groups & 2.770 & 6 & 0.462 & 1.359 & 0.236 \\
& Within Groups & 44.505 & 131 & 0.340 & & \\
& Total & 47.275 & 137 & & & \\
Worn out_lack of & Between Groups & 8.228 & 6 & 1.371 & 2.320 & 0.037 \\
acknowledgement & Within Groups & 77.433 & 131 & 0.591 & & \\
& Total & 85.661 & 137 & & & \\
Worn out_lack of & Between Groups & 11.672 & 6 & 1.945 & 3.673 & 0.002 \\
control & Within Groups & 69.388 & 131 & 0.530 & & \\
Total & 81.060 & 137 & & & \\
\hline
\end{tabular}

trol. Means by dimensions can be seen in Figure 5 .

The results follow the earlier mentioned trend. Participants who work up to 5 years and more than 25 years assessed lower level of lack of recognition for their efforts and feeling of helplessness at work.

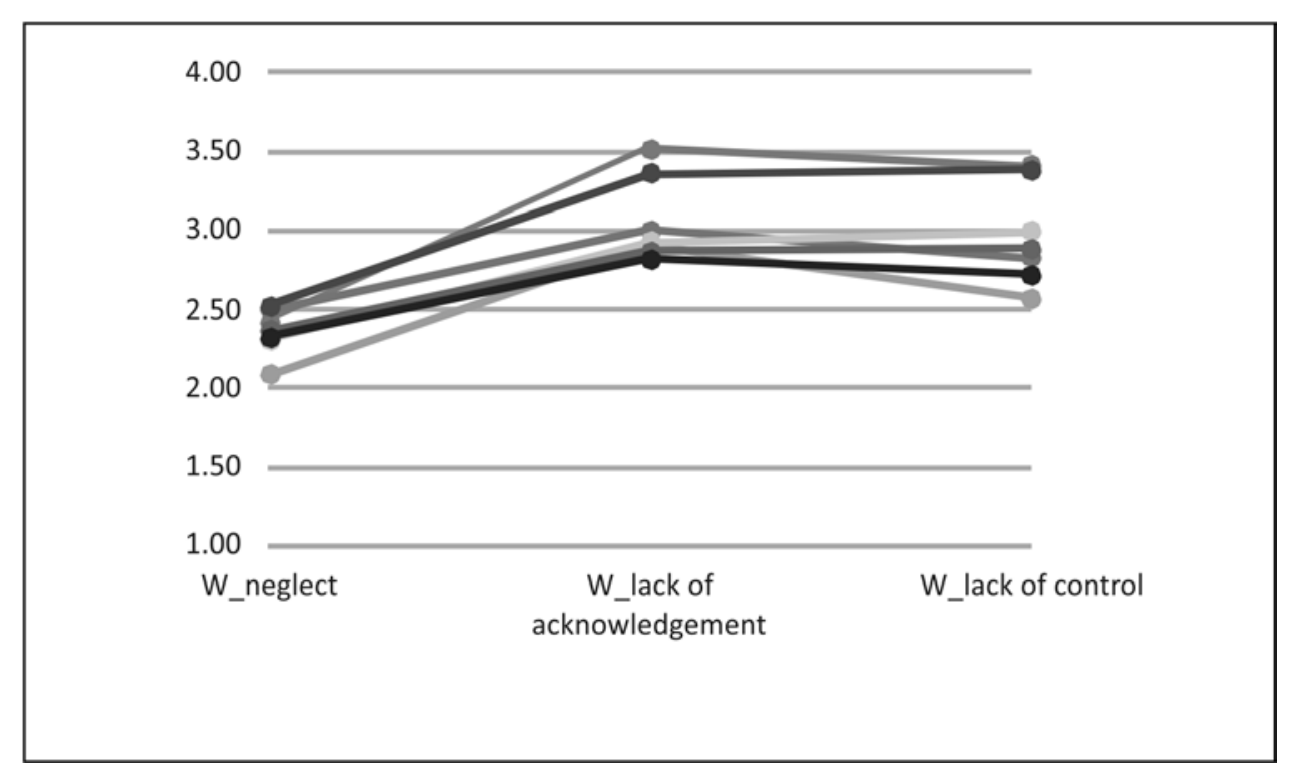

Figure 5. Subscales Worn out dimensions means regarding the participants' length of service 


\section{Discussion}

The results showed that there is moderate burnout experience in the sense that participants feel overload when they try to maximize their reward by taking on a volume and pace of work that become excessive. There are no differences in work stress level regarding the gender and age of the participants which is consistent with some other research results $[17,24,25,16]$.

Participants with higher level of education experience less indifference at work place (carrying out tasks in a superficial manner), less feelings of meaninglessness and they see more opportunities for personal development at work. Besides that, participants with higher level of education feel more commitment to work, experience more acknowledgment in the work and have feelings of more control.

Regarding the personal relationship of participants, the result shows that there are differences in the subscale Frenetic - the highest result have participants who are engaged to be married or the ones in romantic relationships while the lowest results have single participants. This is consistent with the results of Lin et al.[21]. These results can be explained with specific phase in life of people who are in (serious) romantic relationships and higher demands of everyday life in that phase.

Regarding the frequency of participants overtime work, the participants who do not work overtime had the lowest results. It looks like that stress level is highest when overtime work happens "once in a while". It can be explained with the fact that participants who occasionally work overtime perceive the overtime work as an unexpected situation (contrary to frequent overtime work) that has more influence on their personal life and therefore produces the highest level of stress.

Regarding the participants length of service, there are differences in the dimensions lack of acknowledgment and lack of control (subscale Worn out). Participants who work relatively short (up to 5 years) and more than 25 years feel that clients and institution appreciate more their efforts/dedication and that they have more control over the situations at work then other groups of participant. This is consistent with the results of Demir et al. [20]. Also it can be explained with "fresh" enthusiasm of participants who work just a few years and "wisdom" of participants who work for many years (understanding of institution climate and taking the best of work).

In conclusion, based on the results of this research it can be concluded that empowerment and building of coping strategies are needed for mental health workers. Different personal status as a level of education, relationship status, length of services, or work condition can be significant in the stress level that participants experience at work. Investment in education can be strategies to prevent work related stress as well as investment in soft skills training. Besides mentioned, it is important to invest in creating institution climate that will foster teamwork, professional responsibilities, culture of respect and acknowledgement for all (management, professional staff, and patients). By investing in individuals (education/training) and environment (quality standards) at the same time, there is a better chance for success in preventing/reducing the work related stress as interventions influence two, interdependent, arenas. 


\section{Acknowledgments}

None

\section{Conflict of interest}

None to declare

\section{References}

1. Maslach C, Schaufeli WB, Leiter MP. Job burnout. Annu Rev Psychol. 2001;52:397-422.

2. Edwards D, Burnard P, Coyle D, Fothergill A, Hannigan, B. Stress and burnout in community mental health nursing: a review of the literature. J Psychiatr Ment Health Nurs. 2000;7:7-14.

3. Awa WL, Plaumann M, Walter U. Burnout prevention: A review of intervention programs. Patient Educ Couns. 2010;78:184-90.

4. Mutsuhiro N. Work-related stress and psychosomatic medicine. Biopsychosoc Med. 2010 ;4:1.

5. Aiken LH, Clarke SP, Sloane DM, Sochalski J, Silber JH. Hospital nurse staffing and patient mortality, nurse burnout, and job dissatisfaction. JAMA 2002;288:1987-993.

6. Sahraian A, Fazelzadeh A, Mehdizadeh AR, Toobaee SH. Burnout in hospital nurses: a comparison of internal, surgery, psychiatry and burns wards. Int Nurs Rev. 2008;55:62-7.

7. Kumar S. Burnout in psychiatrists. World Psychiatry 2007;6:186-9.

8. Deahl M, Turner T. General psychiatry in noman's land. Br J Psychiatry. 1997;171:6-8.

9. Khamisa N, Oldenburg B, Peltzer K, Ilic D. Work related stress, burnout, job satisfaction and general health of nurses. Int J Environ Res Public Health. 2015;12:652-66.

10. Shailesh K, Hatcher S, Huggard P. Burnout in psychiatrists: an etiological model. Int J Psychiatry Med. 2005;35:405-16.

11. Jenkins R, Elliott P. Stressors, burnout and social support: nurses in acute mental health settings. J Adv Nurs. 2004;48:622-31.
12. Rathod S, Roy L, Ramsay M, Das M, Birtwistle J, Kingdon D. A survey of stress in psychiatrists working in the Wessex Region. Psychiatr Bull. 2000;24:133-6.

13. Jonathon RB, Buckley R. Burnout in organizational life. J Manag. 2004;30:859-79.

14. Langelaan S Bakker AB, van Doornen LJP, Schaufeli WB. Burnout and work engagement: Do individual differences make a difference? Pers Individ Dif. 2006;40:521-32.

15. Piko BF. Burnout, role conflict, job satisfaction and psychosocial health among Hungarian health care staff: a questionnaire survey. Int J Nurs Stud. 2006;43:311-8.

16. Leiter MP, Harvie PL. Burnout among mental health workers: a review and a research agenda. Int J Soc Psychiatry. 1996;42:90-101.

17. Thornton PI. The relation of coping, appraisal, and burnout in mental health workers. JRL J Psychol. 1992;126:261-71.

18. Hoeksema JH, Guy JD, Brown CK, Brady JL. The relationship between psychotherapist burnout and satisfaction with leisure activities. Psychotherapy in Private Practice 1993;12:51-7.

19. Vorkapić ST, Mustapić J. Internal and external factors in professional burnout of substance abuse counsellors in Croatia. Ann Ist Super Sanita. 2012;48:189-97

20. Demir A, Ulusoy M, and Ulusoy MF. Investigation of factors influencing burnout levels in the professional and private lives of nurses. Int J Nurs Stud. 2003;40:807-27.

21. Lin F, St John W, McVeigh C. Burnout among hospital nurses in China. J Nurs Manag. 2009;17:294301. 
22. Chou LP, Li CY, Hu SC. Job stress and burnout in hospital employees: comparisons of different medical professions in a regional hospital in Taiwan. BMJ Open. 2014;4:2

23. Schimp JB. Health Behaviors, Hardiness, and Burnout in Mental Health Workers [dissertation]. Minneapolis, Minnesota Walden University; 2015

24. Aguwa EN, Nduka I, Arinze-Onyia SU. Assessment of burnout among health workers and bankers in Aba south local government area, Abia state, South East Nigeria. Niger J Clin Pract. 2014;17:296-302.

25. Matin HZ, Nader SK, Mohammad RAA. Do Demographic Variables Moderate the Relationship Between Job Burnout and its Consequences? Iranian Journal of Management Studies 2012;5:47.

26. Maslach C, Schaufeli WB, Leiter MP. Job burnout. Annu Rev Psychol. 2001;52:397-422.
27. Lim N, Kyoung KE; Hyunjung K; Eunjoo Y; Sang Min L.. Individual and work-related factors influencing burnout of mental health professionals: a Meta-analysis. J Employment Couns. 2010;47:86-96.

28. Vredenburgh LD, Carlozzi AF, Stein LB. Burnout in counseling psychologists: Type of practice setting and pertinent demographics. Couns Psychol Q. 1999;12:293-302.

29. Farber BA. Subtypes of burnout: theory, research and practice. Annual Conference, American Psychological Association. San Francisco 2001.

30. Montero-Marín J, García-Campayo J. A newer and broader definition of burnout: Validation of the" Burnout Clinical Subtype Questionnaire (BCSQ36)." BMC Public Health. 2010;10:1.

\section{Sindrom sagorijevanja stručnjaka mentalnog zdravlja: psihijatrijska bolnica}

Sažetak - Burnout (sagorijevanje) se često spominje kao pojava u području mentalnog zdravlja. Riječ je o prolongiranom odgovoru na kronične stresore vezane uz posao, te kao takav ima poseban značaj u zdravstvu gdje je emocionalni i fizički stres nerijetko iskustvo osoblja. Cilj rada je odrediti razinu stresa kod stručnjaka koji rade u psihijatrijskoj bolnici, kao i istražiti postoje li razlike u razini stresa obzirom na različite karakteristike sudionika kao što su spol, stupanj obrazovanja, bračni status, radno vrijeme itd. U radu je korišten Upitnik sagorijevanja na poslu sa kliničkim podtipovima (The Burnout Clinical Subtypes Questionnaire - BCSQ). Studija je provedena od srpnja do prosinca 2014., te od travnja do svibnja 2015. Uzorak čini 141 sudionik, stručnjaka u području zaštite mentalnog zdravlja, zaposlenih u psihijatrijskoj bolnici, 39.9\% čine muškarci, a $68.1 \%$ žene, prosječne dobi 38.8 godina. Ukupni rezultati pokazuju da sudionici imaju niže rezultate na svim subskalama. Rezultati su pokazali da postoji umjereno iskustvo sagorijevanja na poslu, na način da će sudionik osjećati preopterećenje kada pokušava povećati svoju naknadu radeći prekovremeno. Ovaj upitnik može biti vrlo koristan instrument za buduće procjene i programiranje intervencija, kao i za različite strategije liječenja pojedinih podtipova sagorijevanja na poslu.

Ključne riječi: burnout (sagorijevanje na poslu), stručnjaci za mentalno zdravlje, psihijatrijska bolnica 